\title{
Recovery of proteins from wastewater of tannery beamhouse operations: influence on the main pollution parameters
}

\author{
A. Marsal, E. Hernández, S. Cuadros, R. Puig, E. Bautista and J. Font
}

\begin{abstract}
$\overline{\text { ABSTRACT }}$
The recovery of proteins from effluents of beamhouse operations in a hair-pulping process of hides is proposed. Precipitation with sulphuric acid at the isoelectric $\mathrm{pH}$ was chosen for protein recovery. The precipitates were characterized in order to study their potential uses. Apart from the protein nitrogen, the precipitate also contained a considerable content of fats resulting from the co-precipitation of natural fat of the hide in the wastewaters. The precipitation of the protein fraction resulted in a reduction of $80-85 \%$ of $C O D$, whereas the protein content decreased $68-78 \%$. This diminution of the contamination load led to a notable reduction of the tax on wastewater. The content of protein material in the precipitate varied from 15 to $44 \%$.

As expected, the protein in the precipitate did not result from the collagen decomposition of the hide but from soluble proteins such as albumin and globulin and remains of keratin.

The precipitates obtained met the maximum limits of heavy metals according to legislation on organic fertilizers. The potential uses of the protein fraction recovered from tannery wastewaters are currently being investigated.
\end{abstract}

Key words | beamhouse operations, contamination diminution, protein recovery, tannery

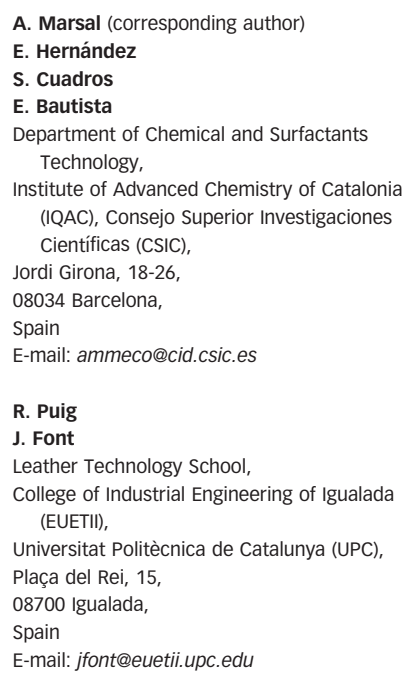

\section{INTRODUCTION}

Most of the contamination arising from the process of transforming raw material into leather is due to the beamhouse operation: $83 \%$ of $\mathrm{BOD}_{5}, 73 \%$ of $\mathrm{COD}$ and $76 \%$ of toxicity (Aloy 1979). Much of the contamination produced in the beamhouse operations results from the solubilization and/or dispersion of different components of hides that end up in wastewaters (Portavella 1995). Of these components, organic nitrogen from solubilized proteins accounts for a significant part of the organic load in wastewater. The elimination of solubilized proteins from wastewaters would considerably reduce the organic nitrogen content with a subsequent diminution of contamination.

The aim of the present work is to develop and implement an economical technique that is easy to apply in tanneries and that allows the recovery of solubilized doi: 10.2166/wst.2010.326 proteins from the effluents of the beamhouse operation for hides. An effective recovery of proteins in the tannery would not only benefit the environment (less contamination) but also the tanners since two parameters of their wastewaters, COD and total nitrogen, would be markedly reduced resulting in a lower environmental tax.

The application of techniques with membranes (ultrafiltration) is one of the most usual methods for protein separation (Ghosh 2003; Feins \& Sirkar 2004). However, ultrafiltration suffers from several problems such as membrane scaling and fouling, weakening of membrane structure (probably due to hydrolysis) etc. (Salmerón \& Salmerón 2005) that shorten the time of the real life of the membranes. All this does not justify the adoption of ultrafiltration by the leather industry in very polluted and concentrated beamhouse wastewater. Nevertheless, 
membranes have been successfully used as a tertiary treatment for reclaiming tannery waters after depuration in a biological treatment plant (Roig et al. 2009).

Likewise, the separation of proteins by precipitation has been widely used in the last decades. Different alternatives exist for the precipitation of proteins: the addition of i) miscible solvents (Rothstein I993; Alzweiri et al. 2008), ii) metallic cations (Simpson 2006), iii) voluminous anions, and iv) polyelectrolytes (Dissing \& Mattiasson I996; Kumar et al. 2003), the precipitation by salting out (Shih et al. 1992; Leonil et al. 1994; Christensen \& Anton 2009) and the precipitation at isoelectric $\mathrm{pH}$ (Hofland et al. 2000). However, in order to develop and implement one of these alternatives in tanneries, aspects such as technical and economic viability as well as the impact on the quality of the wastewater must be considered.

The elimination/recovery of proteins from the wastewater of tanneries has been investigated by several authors. Sekaran et al. (I997) studied the removal of dissolved protein from soaking wastewater by adsorption with activated carbon. The main objective of the work of Vitolo et al. (I999) was the recovery of sodium chloride after the removal of proteins from the wastewater of several operations of the beamhouse process by acid precipitation and subsequent coagulation and filtration. Tünay et al. (200I) and Kabdasli et al. (2003) studied the recovery of solubilized proteins in different tannery wastewaters by acidification, metal salt addition $\left(\mathrm{Cu}^{+2}\right.$ and $\mathrm{Zn}^{+2}$ salts), polyelectrolyte addition and coagulation/flocculation with $\mathrm{AlCl}_{3}$ and $\mathrm{FeCl}_{3} \cdot 6 \mathrm{H}_{2} \mathrm{O}$. According to these studies, acidification of the samples proved to be a satisfactory method to eliminate organic nitrogen from effluents. However, these studies focused neither on the influence of the elimination/recovery of proteins on the pollution/ toxicity values of the resulting wastewaters nor on the characterization of the precipitated protein fraction to evaluate its potential uses. Of these alternatives, Marsal et al. (2009) selected the precipitation of solubilized proteins at the isoelectric $\mathrm{pH}$ because of its technical and economic viability for the recovery of organic nitrogen from wastewaters of beamhouse operations for hides in a hair recovery process. The results obtained revealed that the prospects of the reduction of the contaminant load and the production of a valuable material were higher for the wastewaters of soaking, unhairing-liming, washing and conditioning.

This work focuses on the recovery of protein from the effluents of a hair-pulping beamhouse process for hides by precipitation with sulphuric acid at the isoelectric $\mathrm{pH}$. The diminution of the pollution as a result of protein precipitation was also considered in addition to the characterization of the recovered protein fraction in order to study its potential uses. The study was carried out with wastewaters that offered higher prospects of reducing contamination and of obtaining a valuable material.

It should be noted that the present work refers to the protein precipitation for a hair-pulping beamhouse process, which differs from that previously reported (Marsal et al. 2009), where a hair recovery beamhouse process (with a prior hair immunization operation) was considered. This will enable us to determine the influence exerted by the immunization operation on the composition of the solubilized proteins.

\section{EXPERIMENTAL}

\section{Materials and methods}

In order to achieve the aforementioned objectives, the study was divided into three sections:

1. Formation and characterization of groups of wastewaters of beamhouse operations

2. Determination of the isoelectric point

3. Precipitation and characterization of the protein fraction

The influence of protein precipitation on the diminution of the pollution load and on the tax on wastewater is also presented.

\section{Characterization of wastewaters}

Formation of groups. Samples from wastewater were provided by the Leather Technology School from Igualada (Catalonia, Spain). The wastewater generated from the following operations of a hair-pulping beamhouse process: soaking, unhairing-liming, washing and conditioning were used in the present work. Wastewater of other beamhouse 
operations (deliming, bating, washing and pickling) was not taken since results of a previous work (Marsal et al. 2009) revealed that protein recovery from these latter operations was much lower.

For a more effective protein recovery, two groups of wastewater were formed taking proportional volumes of the total volume of each individual wastewater: Group 1: soaking; Group 2: unhairing-liming, washing and conditioning.

These two groups of wastewater were characterized by determining the following parameters: $\mathrm{pH}$, chemical oxygen demand (COD), total Kjeldhal nitrogen, ammonium nitrogen, total soluble nitrogen (total Kjeldhal nitrogen of filtered bath), total solids and conductivity following the Standard Methods (I998). The following parameters were calculated from the results obtained: particulate nitrogen (total nitrogen-soluble nitrogen), organic nitrogen (total nitrogen-ammonium nitrogen) and dissolved protein (organic nitrogen $\times 5.62$ ).

Toxicity was measured by means of the Photobacterium phosphoreum luminescence reduction test (Microtox Test) (DIN I997).

\section{Determination of the isoelectric point}

The value of $\mathrm{pH}$ of wastewaters was adjusted by a series of sodium acetate/acetic acid buffers that had a $\mathrm{pH}$ range from 2.8 to 8.0 to determine the isoelectric point (Miller 200I). The isoelectric point corresponds to the minimum of the graph protein concentration vs. $\mathrm{pH}$. The protein concentration was determined in the supernatant resulting from the addition of the buffer and subsequent separation of the precipitated protein by centrifugation. The method used in the determination of protein concentration was the spectrophotometric method of bicinchoninic acid (Smith et al. I985). This method is based on the reduction of $\mathrm{Cu}^{+2}$ to $\mathrm{Cu}^{+1}$ by protein and subsequent chelation of two molecules of bicinchoninic acid with one cuprous ion. The complex formed exhibits a strong absorbance at $562 \mathrm{~nm}$, which is nearly linear with increasing protein concentration.

\section{Precipitation}

Characterization of the precipitate. Precipitation of the protein fraction was performed by adding $2 \mathrm{M}$ Sulphuric acid solution up to the isoelectric point. Once precipitated, the protein fraction was filtered off and the supernatants were characterized by determining the same parameters as for the original wastewaters.

The precipitates were characterized by determining the quantitative composition of the major components: humidity was determined by the weight loss after drying the sample at $102^{\circ} \mathrm{C}$ for 12 hours; fats were assessed by extracting the sample with dichloromethane for five hours and $a s h$ was determined by placing the sample in a muffle at $550^{\circ} \mathrm{C}$ for 2 hours. Humidity, fats and ash were determined by adapting the SLTC official methods of analysis (I996); total nitrogen was determined by the Kjeldhal method (Standard Methods I998); HPLC was used for the evaluation of free amino acids by the AccQTAG method (Waters 200I). The AccQTag method is based on the pre-column derivatization with 6-aminoquinolyl-N-hydroxisuccinimidyl carbamate reactive (ACQ), which forms stable derivatives with primary and secondary amino acids. The derivatives are easily separated by reversed phase HPLC. The content of heavy metals, calcium, magnesium, sodium and potassium was determined by atomic emission spectrophotometry by Inductively Coupled Plasma (ICP-OES) after acid digestion according to EN 13650:200I Standard. The composition of total amino acids was evaluated following the AccQTAG method after acid hydrolysis of the protein fraction with HCI $6 \mathrm{~N}$.

It should be noted that at industrial scale, the resulting acidic wastewaters obtained after protein precipitation must be mixed with those of subsequent industrial processes and must be neutralized after homogenization if the resulting $\mathrm{pH}$ is below 6 . Thereafter, the neutralized wastewater is sent to the Biological Wastewater Treatment Plant.

\section{RESULTS AND DISCUSSION}

Tables 1, 2, 5, 6 and 7 show the experimental results expressed as the mean values of three replicates \pm standard deviation.

\section{Diminution of the contamination load}

Tables 1 and 2 show the influence of acid precipitation on the characteristics of wastewaters of Group 1 and 2, 
Table 1 | Influence of acid precipitation on the characteristics of wastewaters of Group 1. Variation of the most significant parameters applicable to wastewater tax

\begin{tabular}{|c|c|c|c|}
\hline Measured parameters & $\begin{array}{l}\text { Group } 1 \\
\text { Before acid precipitation }\end{array}$ & After acid precipitation & Variation (\%) \\
\hline $\mathrm{pH}$ & $6.4 \pm 0.2$ & $3.4 \pm 0.2$ & \\
\hline $\mathrm{COD}\left(\mathrm{mg} \mathrm{O}_{2} / \mathrm{L}\right)$ & $13,700 \pm 300$ & $2,850 \pm 50$ & $\downarrow 79$ \\
\hline Total N (mg/L) & $268 \pm 7$ & $145 \pm 3$ & $\downarrow 46$ \\
\hline Ammonium $\mathrm{N}(\mathrm{mg} / \mathrm{L})$ & $96 \pm 1$ & $90 \pm 1$ & $\downarrow 7$ \\
\hline Soluble N (mg/L) & $187 \pm 3$ & $145 \pm 3$ & $\downarrow 23$ \\
\hline Total solids (\%) & $3.36 \pm 0.01$ & NA & \\
\hline Conductivity (mS/cm) & $46.55 \pm 2.35$ & $48.35 \pm 1.15$ & $\uparrow 4$ \\
\hline Toxicity (equitox $\left./ \mathrm{m}^{3}\right)^{*}$ & ND & ND & $=$ \\
\hline \multicolumn{4}{|l|}{ Calculated parameters } \\
\hline Particulate N (mg/L) & 81.7 & NA & \\
\hline Organic N (mg/L) & 172 & 55.1 & $\downarrow 68$ \\
\hline Protein $(\mathrm{mg} / \mathrm{L})$ & 968 & 309 & $\downarrow 68$ \\
\hline
\end{tabular}

*Equitox/m³: 100/EC50 (EC50 expressed in \%).

ND: not detected; NA: not analysed. The most significant parameters applicable to water tax for wastewaters are in bold.

respectively. The characterization of the untreated wastewaters (before acid precipitation) shows a protein content, which is higher for Group 2 (Table 2) than for Group 1 (Table 1). The wastewater of Group 2 contains the residues of the dissolved hair produced by alkaline hydrolysis in the unhairing-liming operation (Merrill I978). In the case of a beamhouse process with hair recovery (Marsal et al. 2009), the immunization operation allows the hair to be physically recovered and, consequently, the value of protein content is markedly lower.

Table 2 also shows a COD value of Group 2 that considerably exceeds the value of Group 1 (Table 1). This is due to the increased protein content of Group 2. Likewise, the addition of a bactericide immediately before

Table 2 | Influence of acid precipitation on the characteristics of wastewaters of Group 2. Variation of the most significant parameters applicable to wastewater tax

\begin{tabular}{|c|c|c|c|}
\hline \multirow[b]{2}{*}{ Measured parameters } & \multicolumn{3}{|l|}{ Group 2} \\
\hline & Before acid precipitation & After acid precipitation & Variation (\%) \\
\hline $\mathrm{pH}$ & $12.0 \pm 0.2$ & $3.7 \pm 0.2$ & \\
\hline $\operatorname{COD}\left(\mathrm{mg} \mathrm{O}_{2} / \mathrm{L}\right)$ & $47,800 \pm 850$ & $7,254 \pm 200$ & $\downarrow 85$ \\
\hline Total N (mg/L) & $3,745 \pm 176$ & $930 \pm 14$ & $\downarrow 75$ \\
\hline Ammonium N (mg/L) & $490 \pm 80$ & $209 \pm 3$ & $\downarrow 57$ \\
\hline Soluble N (mg/L) & $2,970 \pm 150$ & $930 \pm 14$ & $\downarrow 69$ \\
\hline Total solids $(\%)$ & $5.3 \pm 0.6$ & NA & \\
\hline Conductivity (mS/cm) & $31.40 \pm 0.20$ & $30.50 \pm 0.21$ & $\downarrow 3$ \\
\hline Toxicity (equitox $\left./ \mathrm{m}^{3}\right)^{*}$ & 5,000 & 67 & $\downarrow 99$ \\
\hline \multicolumn{4}{|l|}{ Calculated parameters } \\
\hline Particulate N (mg/L) & 774 & NA & \\
\hline Organic N (mg/L) & 3259 & 721 & $\downarrow 78$ \\
\hline Protein $(m g / L)$ & 18,316 & 4,052 & $\downarrow 78$ \\
\hline
\end{tabular}

*Equitox/m³: 100/EC50 (EC50 expressed in \%).

NA: not analysed. The most significant parameters applicable to water tax for wastewaters are in bold. 
the unhairing-liming operation resulted in a high toxicity of Group 2 in contrast to the non-toxicity of Group 1.

Although no large differences were observed in a wide $\mathrm{pH}$ range, the values of $\mathrm{pH} 3.8$ and 3.9 were obtained for the isoelectric point of Groups 1 and 2, respectively. Tables 1 and 2 give the results obtained after protein precipitation. A clear reduction in most of the parameters is observed mainly for wastewater of Group 2. The protein content shows a $68 \%$ decrease for Group 1 (Table 1) and a 78\% decrease for Group 2 (Table 2). Tünay et al. (200I) obtained $90 \%$ protein removal by acidification at a $\mathrm{pH}$ value of 4.6 for sheepskin wastewater, and 50\% efficiency was obtained by acidification at a $\mathrm{pH}<5$ for bovine hide wastewater. A diminution of 79\% (Group 1) and 85\% (Group 2) of the COD values is noted. These values are consistent with those of Vitolo et al. (1999), who found values of COD reduction between $60-90 \%$. The high reduction of COD could be attributed to the fact that emulsified and suspended fats in wastewater from hide fleshings underwent co-precipitation with proteins. This could be corroborated by the characterization of the precipitate.

Another important effect of the precipitation with sulphuric acid is noted in the toxicity of the wastewater of Group 2, which shows a decrease of approximately 99\% (Table 2). This important diminution in toxicity mainly results from the elimination of the bactericide, which is produced in the precipitation and subsequent filtration. However, further studies will be performed to confirm this hypothesis.

\section{Influence of the diminution of the contamination load on the tax on wastewater}

The 3/2003 Decree of 4 November governs the water tax, an environmental levy that takes into account the volume of water used and its level of contamination. (Generalitat de Catalunya 2003).

The contribution of the level of contamination to the water tax is calculated from the cost of the contamination parameters shown in Table 3.

The water tax is calculated from:

Water $\operatorname{tax}(€)=$ taxable base $\left(\mathrm{m}^{3}\right) \times$ type of obligation $\left(€ / \mathrm{m}^{3}\right)$

Table 4 indicates the price to be paid per $\mathrm{m}^{3}$ for Group 1 and Group 2, respectively, as a function of the effluent
Table 3 | Cost of the contamination parameter to evaluate the water tax

\begin{tabular}{ll} 
Contamination parameter & Parameter cost (2009) \\
\hline Suspended matter $(\mathrm{SM})$ & $0.3980 € / \mathrm{Kg}$ \\
Oxidizable matter $(\mathrm{OM})$ & $0.7963 € / \mathrm{Kg}$ \\
Soluble salts $(\mathrm{SS})$ & $6.3705 € /\left(\mathrm{S} \mathrm{cm}^{-1} \mathrm{~m}^{3}\right)$ \\
Inhibiting matter $(\mathrm{IM})$ & $9.4438 € / \mathrm{Kequitox}$ \\
Nitrogen $(\mathrm{N})$ & $0.6045 € / \mathrm{Kg}$ \\
Phosphorus $(\mathrm{P})$ & $1.2092 € / \mathrm{Kg}$ \\
\hline
\end{tabular}

The units of the "Soluble Salts" parameter are "conductivity" $\left(\mathrm{S} \mathrm{cm}^{-1}\right)$ multiplied by "volume" of water $\left(\mathrm{m}^{3}\right)$.

discharged by the industry. These figures are calculated with the prices for the year 2009 (VAT excluded).

As may be observed, the precipitation of wastewaters of the first beamhouse operations before discharge would mean a saving of $75.7 € / \mathrm{m}^{3}$ as far as the contamination parameters are concerned. Taking into account that the cost of precipitation is $0.5 € / \mathrm{m}^{3}$, the cost saved on taxes would be $75.2 € / \mathrm{m}^{3}$. This saving would be $28.6 € / \mathrm{m}^{3}$ if the bactericide is not added or if the tannery discharges the beamhouse wastewater that is mixed with wastewater of subsequent processes (this would eliminate the bactericide from the wastewater). In these cases the inhibiting matter parameter is not considered.

In any case, this means a considerable saving, especially for tanneries specialized only in beamhouse operations since they do not have other types of wastewaters at acid pHs for mixing.

The effect of the reduced contamination load on tax on wastewater in Catalonia (Spain), where the work was carried out, is regarded as an example of the saving that tanners can make by simply precipitating the protein fraction from the wastewaters of the initial beamhouse operations.

\section{Characterization of the precipitate obtained by addition of sulphuric acid}

The precipitation at the isoelectric point generated 6 and $15 \mathrm{~g}$ of dry precipitate per $\mathrm{L}$ of acidified wastewater for Groups 1 and 2, respectively. The characterization of the precipitate obtained yielded the following results: 
Table 4 | Tax calculated for each type of discharge

\begin{tabular}{|c|c|c|c|c|c|c|}
\hline Contamination parameter & $\begin{array}{l}\text { Group } 1 \\
\text { Initial waste } \\
\text { water }\left(€ / \mathbf{m}^{3}\right)\end{array}$ & $\begin{array}{l}\text { Wastewater precipitated } \\
\text { and filtered }\left(€ / \mathbf{m}^{3}\right)\end{array}$ & $\begin{array}{l}\text { Difference } \\
\left(€ / \mathrm{m}^{3}\right)\end{array}$ & $\begin{array}{l}\text { Group } 2 \\
\text { Initial waste } \\
\text { water }\left(€ / \mathbf{m}^{3}\right)\end{array}$ & $\begin{array}{l}\text { Wastewater precipitated } \\
\text { and filtered }\left(€ / \mathbf{m}^{3}\right)\end{array}$ & $\begin{array}{l}\text { Difference } \\
\left(€ / \mathbf{m}^{3}\right)\end{array}$ \\
\hline Oxidizable matter & 7.3 & 1.5 & $\downarrow 5.8$ & 25.4 & 3.9 & $\downarrow 21.5$ \\
\hline Soluble salts & 0.3 & 0.3 & 0.0 & 0.2 & 0.2 & 0.0 \\
\hline Nitrogen & 0.2 & 0.1 & $\downarrow 0.1$ & 2.3 & 0.6 & $\downarrow 1.7$ \\
\hline \multirow[t]{3}{*}{ Inhibiting matter } & 0.0 & 0.0 & 0.0 & 47.2 & 0.6 & $\downarrow 46.6$ \\
\hline & & Subtotal & $\downarrow 5.9$ & & Subtotal & $\downarrow 69.8$ \\
\hline & & & & & Total & $\downarrow 75.7$ \\
\hline
\end{tabular}

\section{Major components}

Table 5 shows the composition of the precipitate obtained by the addition of $2 \mathrm{M}$ sulphuric acid solution to wastewaters of Groups 1 and 2. The remarkably low protein content $(15 \%)$ and the extraordinarily high content of fats $(65.4 \%)$ in the precipitate of Group 1 should be noted. This confirms the occurrence of a significant co-precipitation of fats when the precipitation of proteins is performed. This co-precipitation of fats increases COD diminution.

The AccQTag method confirmed that the majority of the amino acids in the samples are combined in the form of proteins or peptides, especially in the case of Group 1 in which only $0.20 \%$ by weight of the precipitate was constituted by free amino acids. In contrast, Group 2 showed a higher content of free amino acids (6.4\%), 37\% of which corresponded to cystine.

Table 5 | Composition of the precipitate obtained with sulphuric acid

\begin{tabular}{lcc} 
Measured parameters & Group 1 (\%) & Group 2 (\%) \\
\hline Humidity & $4.9 \pm 0.5$ & $9.6 \pm 0.7$ \\
Total nitrogen & $2.7 \pm 0.3$ & $7.8 \pm 0.2$ \\
Ammonium nitrogen & - & - \\
Organic nitrogen & $2.7 \pm 0.3$ & $7.8 \pm 0.2$ \\
Free amino acids & $0.20 \pm 0.05$ & $6.4 \pm 1.0$ \\
Fat and other substances soluble in & $65.4 \pm 0.5$ & $19.4 \pm 0.1$ \\
$\quad$ dichloromethane & & \\
Ash & $15.9 \pm 0.3$ & $28.5 \pm 0.1$ \\
Calculated parameters & & \\
Protein & 15 & 44 \\
\hline
\end{tabular}

\section{Composition of amino acids}

The analysis of the total amino acids of the precipitated protein fraction revealed the remarkably low content of hydroxyproline. This amino acid is characteristic of collagen (it may contain up to $12 \% \mathrm{w} / \mathrm{w}$ ) (Bowes et al. I955). Given that hydroxyproline is usually employed as an analytical criterion to evaluate the amount of collagen present in protein derivatives, it may be concluded that the origin of the protein present in the precipitate is not the decomposition of collagen of the hide but the soluble proteins such as albumin and globulin.

The protein fraction of Group 2 also contains remains of keratin since $6.5 \%$ of the total amino acids corresponded to cystine. This value contrasts with the lower content of cystine in Group $1(1.8 \%)$. The higher content of cystine in Group 2 results from the alkaline hydrolysis of hair caused by sodium sulphide and calcium hydroxide used in the unhairing-liming operation (Merrill i978).

Amino acids can directly or indirectly enhance the physiological activities of plants (Rauser I990; Naidu et al. I99I). The following eighteen amino acids were detected in the precipitated protein of Group 2: arginine, histidine, lysine, aspartic acid, glutamic acid, serine, threonine, cystine, glycine, proline, alanine, leucine, methionine, phenylalanine, valine, isoleucine, tyrosine and hydroxyproline. Some of them are recognized to have a very positive effect on plants. (Ashmed et al. 1986).

\section{Composition of ash}

The high percentage of ash should be noted mainly in Group 2 (Table 5). The content of heavy metals (listed in 
Table 6 | Content of the main alkali and alkaline earth metals in the precipitate in the form of oxide and in the form of sulphate

\begin{tabular}{|c|c|c|c|c|c|c|c|}
\hline \multicolumn{4}{|l|}{ Group 1} & \multicolumn{4}{|l|}{ Group 2} \\
\hline $\mathrm{CaO}$ & $0.23 \pm 0.02$ & $\mathrm{CaSO}_{4}$ & 0.56 & $\mathrm{CaO}$ & $4.4 \pm 0.5$ & $\mathrm{CaSO}_{4}$ & 10.6 \\
\hline $\mathrm{MgO}$ & $0.040 \pm 0.002$ & $\mathrm{MgSO}_{4}$ & 0.12 & $\mathrm{MgO}$ & $0.050 \pm 0.002$ & $\mathrm{MgSO}_{4}$ & 0.15 \\
\hline $\mathrm{Na}_{2} \mathrm{O}$ & $3.92 \pm 0.02$ & $\mathrm{Na}_{2} \mathrm{SO}_{4}$ & 8.98 & $\mathrm{Na}_{2} \mathrm{O}$ & $4.2 \pm 0.2$ & $\mathrm{Na}_{2} \mathrm{SO}_{4}$ & 9.6 \\
\hline $\mathrm{K}_{2} \mathrm{O}$ & $0.10 \pm 0.01$ & $\mathrm{~K}_{2} \mathrm{SO}_{4}$ & 0.19 & $\mathrm{~K}_{2} \mathrm{O}$ & $0.06 \pm 0.02$ & $\mathrm{~K}_{2} \mathrm{SO}_{4}$ & 0.11 \\
\hline Total & $\sim 4.30$ & Total & $\sim 9.90$ & Total & $\sim 8.70$ & Total & $\sim 20.5$ \\
\hline
\end{tabular}

Table 7 Content of heavy metals in proteins obtained expressed on dry weight

\begin{tabular}{|c|c|c|c|c|c|c|c|}
\hline & \multicolumn{7}{|c|}{ Heavy metal (mg/kg) } \\
\hline & cd & $\mathrm{Cu}$ & $\mathbf{N i}$ & $\mathbf{z n}$ & cr & $\mathbf{P b}$ & $\mathrm{Hg}$ \\
\hline Group 1 & ND & $7.6 \pm 0.1$ & $1.8 \pm 0.2$ & $13.0 \pm 0.3$ & $63.8 \pm 0.5$ & ND & ND \\
\hline Group 2 & ND & $11.3 \pm 0.5$ & $9.2 \pm 0.6$ & $89.4 \pm 0.5$ & $14.7 \pm 0.3$ & ND & ND \\
\hline $\begin{array}{l}\text { Maximum limits } \\
\quad(\text { EC 2003/2003) }\end{array}$ & 0.7 & 70 & 25 & 200 & 70 & 45 & 0.4 \\
\hline
\end{tabular}

The bottom row shows the maximum limits permitted in class A fertilizers according to EC 2003/2003 European regulation; ND: not detected.

the section below) and alkali and alkaline earth metals were determined. The results obtained for the latter components are shown in Table 6, which are also expressed in the form of sulphates.

As expected, the ash composition shows a high concentration of sodium salts in the precipitate of Group 1, which comes from the salt used in the curing process (Heidemann I993), whereas the material obtained in Group 2 is rich in calcium salts coming from the calcium hydroxide used in the liming operation (Lollar I978).

The content of phosphorus expressed as $\mathrm{P}_{2} \mathrm{O}_{5}$ was $0.2 \%$ and $<0.1 \%$ (on dry weight of the precipitate) for Group 1 and Group 2, respectively.

\section{Content of heavy metals}

Table 7 gives the content of heavy metals in the precipitates obtained for Groups 1 and 2 by precipitation with sulphuric acid.

Should this precipitate be used as a fertilizer, this parameter assumes an especial importance given that Spanish and European legislation demands the use of materials with negligible amounts of heavy metals to avoid their dissemination in the environment through fertilizers that originate from recovered organic materials.

Table 7 shows that the precipitates obtained meet the maximum limits of heavy metals in class A fertilizers. These limits are the most restrictive of the EC 2003/2003 European Regulation governing fertilizers (European Parliament 2003).

The detection limits of cadmium, lead and mercury in the analysis conditions are $0.6 \mathrm{mg} / \mathrm{kg}, 3.0 \mathrm{mg} / \mathrm{kg}$ and $0.3 \mathrm{mg} / \mathrm{kg}$, respectively.

\section{CONCLUSIONS}

The isoelectric precipitation of solubilized proteins in wastewaters of the initial operations of a hair-pulping beamhouse process constitutes an alternative approach to the reduction of the contaminant load and the recovery of a valuable material (the precipitated protein fraction). This simple operation resulted in a major diminution of COD values and protein content. Emulsified and suspended fats in wastewater from hide fleshings experienced co-precipitation with proteins, increasing COD 
diminution. Another important result was the drastic decrease in the toxicity of the wastewater due to the elimination of a bactericide added in the initial stages of the beamhouse process. This represents an important saving on the cost of wastewater treatment and associated taxes.

Peptides and proteins make up most of the precipitated protein fraction. They could be reduced in molecular size for use as organic fertilizers by means of controlled hydrolysis. The protein present in the precipitate did not result from the collagen decomposition of the hide but from soluble proteins such as albumin and globulin and remains of keratin.

Although our results show that the precipitated protein fraction meets all the requirements for use as organic fertilizers, further studies are warranted to confirm this hypothesis. In addition, the potential use of amino acids obtained by acid hydrolysis of the precipitated protein fraction for the production of amino acid-based surfactants as well as the application of this protein material as a retanning agent for tannery is currently being investigated.

\section{ACKNOWLEDGEMENTS}

The authors would like to acknowledge the Spanish Ministry of Education and Science for funding obtained through the CTQ 2006-08106/PPQ Project, which allowed them to undertake the present study.

\section{REFERENCES}

Aloy, M. I979 Tannerie et Pollution (Tannery and Pollution), Centre Technique du Cuir (ed.), Lyon, France.

Alzweiri, M., Watson, D. G., Robertson, C., Sills, G. J. \& Parkinson, J. A. 2008 Comparison of different water-miscible solvents for the preparation of plasma and urine samples in metabolic profiling studies. Talanta 74(4), 1060-1065.

Ashmead, H. D., Ashmead, H. H., Miller, G. W. \& Hsu, H. H. I986 Foliar Feedings of Plants with Amino Acid Chelates, 1st edition. Noyes Publications, Park Ridge, New Jersey, USA.

Bowes, J. H., Elliot, R. G. \& Moss, J. A. 1955 Composition of collagen and acid-soluble collagen of bovine skin. Biochem. J. 61(1), 143-150.

Christensen, T. \& Anton, J. 2009 Two-Phase Precipitation of Proteins, Patent Application 20090286966, Novo Nordisk A/S, Princeton, New Jersey, USA.
DIN (Deutches Institut für Normung) 38412-34 1997 German standard methods for the examination of water, wastewater and sludge. Bio-assays (group L) Part-34. Determination of the inhibitory effect of wastewater on the light emission of Photobacterium phosphoreum; luminescent bacteria wastewater test using conserved bacteria.

Dissing, U. \& Mattiasson, B. 1996 Polyelectrolyte complexes as vehicles for affinity precipitation of proteins. J. Biotechnol. 52(1), 1-20.

EN (European Normalization) 13650 200I Standard. Soil improvers and growing media. Extraction of aqua regia soluble elements.

European Parliament 2003 EC 2003/2003 Regulation of the European Parliament and of the Council of 13th October 2003 relating to fertilisers, Official Journal of the European Union number L304, 21st November 2003.

Feins, M. \& Sirkar, K. K. 2004 Highly selective membranes in protein ultrafiltration. Biotechnol. Bioeng. 86(6), 603-611.

Generalitat de Catalunya 2003 3/2003 Decree on Revised texts of the legislation on water in Catalonia, Diari Oficial de la Generalitat de Catalunya (Official Journal of Catalonia Government) number 4015, 21st November 2003.

Ghosh, R. 2003 Protein Bioseparation using Ultrafiltration: Theory, Applications and New Developments. Imperial College Press, London, England.

Heidemann, E. 1993 Eduard Roether, K. G. (ed.) Fundamentals of Leather Manufacturing, Darmstadt, Germany.

Hofland, G. W., deRijke, A., Thiering, R., van der Wielen, L. A. M. \& Witkamp, G. J. 2000 Isoelectric precipitation of soybean protein using carbon dioxide as a volatile acid. J. Chromatog. B: Biomed. Sci. Appl. 743(1-2), 357-368.

Kabdasli, I., Olmez, T. \& Tünay, O. 2003 Nitrogen removal from tannery wastewater by protein recovery. Water Sci. Technol. 48(1), 215-223.

Kumar, A., Galaev, I. Y. \& Mattiason, B. 2003 Precipitation of proteins: nonspecific and specific. In: Hatti-Kaul, R. \& Mattiason, B. (eds) Isolation and Purification of Proteins. Marcel Dekker Inc, New York, USA, pp. 225-277.

Leonil, J., Molle, D., Bouhallab, S. \& Henry, G. 1994 Precipitation of hydrophobic peptides from tryptic casein hydrolysate salt and pH. Enzyme Microb. Technol. 16(7), 591-595.

Lollar, R. M. 1978 The chemistry of liming. In: O'Flaherty, F., Roddy, W. T. \& Lollar, R. M. (eds) The Chemistry and Technology of Leather, 2 edition. Robert E. Krieger Publishing Company, Malabar, Florida, USA, pp. 297-322.

Marsal, A., Bautista, E., Cuadros, S., Reyes, M. A., Rius, A. \& Font, J. 2009 Recovery of organic nitrogen from beamhouse wastewater in a hair recovery process. J. Soc. Leather Technol. Chem. 93(5), 176-182.

Merill, H. B. 1978 The mechanism of unhairing. In: O'Flaherty, F., Roddy, W. T. \& Lollar, R. M. (eds) The Chemistry and Technology of Leather, 2nd edition. Robert E. Krieger Publishing Company, Malabar, Florida, USA, pp. 257-296.

Miller, D. D. 20or Química de alimentos. Manual de laboratorio (Food chemistry. Laboratory practices) Limusa-Wiley Library. http:// www.libreria-limusa-wiley.com (accessed on March 16th 2010). 
Naidu, B. P., Paleg, L. G., Aspinall, D., Jennings, A. C. \& Jones, G. P. I99I Amino-acid and glycine betaine accumulation in cold-stressed wheat seedlings. Phytochemistry 30(2), 407-409.

Portavella, M. I995 Tenería y medio ambiente: aguas residuales (tannery and environment: wastewaters). In: Cícero (ed.) Tecnología del Cuero (Leather Technology), (Vol. 4), Barcelona, Spain, pp. 89-198.

Rauser, W. E. I99o Phytochelatins. In: Richardson, C. C., Abelson, J. N., Meister, A. \& Walsh, C. T. (eds) Annual Review of Biochemistry, (Vol. 59). Annuals Reviews Inc., Palo Alto, California, USA, pp. 61-86.

Roig, J., Font, J., Marginet, X., Jorba, M., Ollé, L., Bacardit, A. \& Puig, R. 2009 Wastewater reutilization in the leather industry using membrane technology. J. Am. Leather Chem. Assoc. 104(4), 139-148.

Rothstein, F. 1993 Differential precipitation of proteins. Science and technology. In: Harrison, R. G. (ed.) Protein Purification Process Engineering. Marcel Dekker Inc., New York, USA.

Salmerón, J. \& Salmerón, J. L. 2005 The problem of salinity in tannery effluents. Proceedings of the AQEIC conference on "The salinity in the leather sector", Valencia, Spain. 9th September, pp. 3-32

Sekaran, G., Mariappan, M. \& Raghavan, K. V. 1997 Protein removal from salt-laden wastewater by activated carbon. Indian J. Chem. Technol. 4(2), 77-82.
Shih, Y. C., Prausnitz, J. M. \& Blanch, H. W. 1992 Some characteristics of protein precipitation by salts. Biotechnol. Bioeng. 40(10), 1155-1164.

Simpson, R. J. 2006 Fractional precipitation of proteins by ammonium sulphate. Cold Spring Harb. Protc. (doi:10.1101/pdb.prot4309).

SLTC Official Methods of Analysis 1996 Society of Leather Technologists and Chemists, Northampton, England.

Smith, P. K., Krohn, R. I., Hermanson, G. T., Mallia, A. K., Gartner, F. H., Provenzano, E. K., Fujimoto, E. K., Goeke, N. M., Olson, B. J. \& Klenk, D. C. I985 Measurement of protein using bicinchoninic acid. Anal. Biochem. 150(1), 76-85.

Standard Methods for the Examination of Water and Wastewater I998 20th edition. American Public Health Association/ American Water Works Association/Water Pollution Control Federation, Washington, DC, USA.

Tünay, O., Koca, T. \& Kabdasli, I. 20or Protein removal and recovery from leather tanning industry wastewaters. Fresenius Environ. Bull. 10(2), 170-173.

Vitolo, S., Berti, P. \& Ansiati, A. 1999 Recupero delle proteine idrosolubilli e dei cloruri dai bagni esausti dei processi di riviera (Recovery of the water-soluble proteins and chloride from wastewater of the beamhouse process). Cuoio Pelli Materie Concianti 75(4), 163-168.

Waters 20oI The Use of 6-Aminoquinolyl-N-Hydroxy Succinimidyl Carbamate Derivatives for HPLC/MS Analysis of Amino Acids, Library Number:Watersamd35, http://www.waters. com/waters/home.htm, (accessed on March 18th 2010). 